\title{
Cytomixis in Pollen Mother Cells of an Apomictic Ornamental Ervatamia divaricata (Linn.) Alston
}

\author{
Mantu De and A. K. Sharma \\ Centre of Advanced Study on Cell and Chromosome Research, \\ Department of Botany, University of Calcutta, \\ Calcutta-700019, India
}

Received April 25, 1981

The occurrence of cytomixis is well known in several families of flowering plants (Bell 1964, Cheng 1974, Cheng et al. 1975, Gottschalk 1970, Kamra 1960, Narain 1979, Omara 1976, Srivastav and Raina 1980). In addition to meiotic cells it has been reported to occur in meristematic tissues (Jacob 1941, Sarvella 1958, Tarkowska $1960,1965)$ and in the interface between somatic and meiotic cells (Cooper 1952). In view of its importance in securing fusion artificially, induction in root tips, shoot tips and tapetal cells has been secured in Vicia faba through treatment with the herbicide trifluraline (Bobak and Herich 1978). The correlation, if any, with the multiplication of genome has been studied in Prunus where diploid, tetraploid and hexaploid forms do not show cytomixis. However, it has been reported in natural and artificial triploid hybrids of this genus (Salesses 1970). In sugarbeet, the frequency is more in triploid and autotetraploid than in diploid (Semyarkhina and Kuptsou 1974).

In course of present investigation in Apocynaceae cytomixis was recorded in a widely used ornamental, Ervatamia divaricata (Linn.) Alston var. single. The present investigation deals with detailed analysis of this phenomenon and its significance in this species.

\section{Materials and methods}

Flower buds of Ervatamia divaricata (Linn.) Alston var. single, were fixed for 8-24 hours at room temperature in Newcomer's fluid (6:3:1:1:1), propionic alcohol and in $40 \%$ formaldehyde - propionic alcohol (1:2:15) for cytological and histological studies respectively (vide Sharma and Sharma 1980). The buds were stored in $70 \%$ ethyl alcohol at $10-12{ }^{\circ} \mathrm{C}$. Fuchsin staining and $2 \%$ propionic carmine staining were used for meiosis and pollen grain sterility studies. Investigations were carried out almost throughout the year from fixed and fresh flower buds collected from five different plants.

\section{Observations}

Occurrence of cytomixis was noted in pollen mother cells of both fixed and fresh flower buds collected almost throughout the year. But the frequency of cyto- 
mixis was found to be more in buds fixed during the months of March to June (Table 1) in all the plants. In fresh buds cytomixis was observed occasionally (Figs. 1-3). No correlation was observed between the anthers of a single flower bud in the frequency of cytomixis. In some cases most of the pollen mother cells of an anther were found to be involved in cytomixis, while the adjacent anthers were seen with

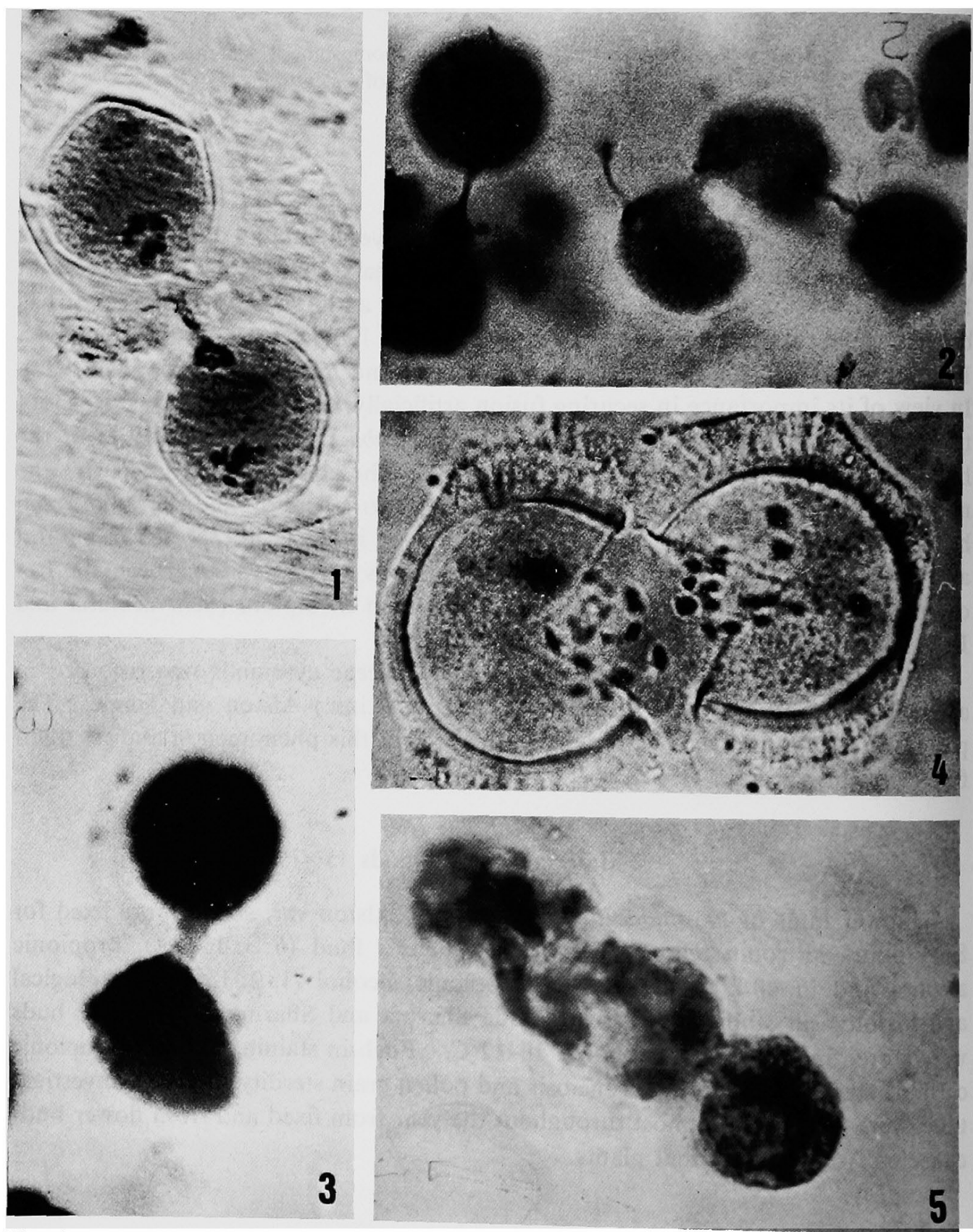

Figs. 1-5. Ervatamia divaricata (Linn.) Alston var. single. 1-3, PMC's showing cytomixis at different stages of meiosis, note the protoplasmic strands and chromatin material in Fig. 1. Fig. 1. $\times 270 ; 2-3 . \times 1880$ (approx). 4-5, PCM's showing direct fusion during meiosis. Fig. 4. $\times 3460$; 
traces of cytomixis or were quite normal without any cytomictic pollen mother cell. Direct fusion of two pollen mother cells was also observed in certain instances (Figs. 4, 5).

This plant, like all other members of Apocynaceae, has five anthers which are
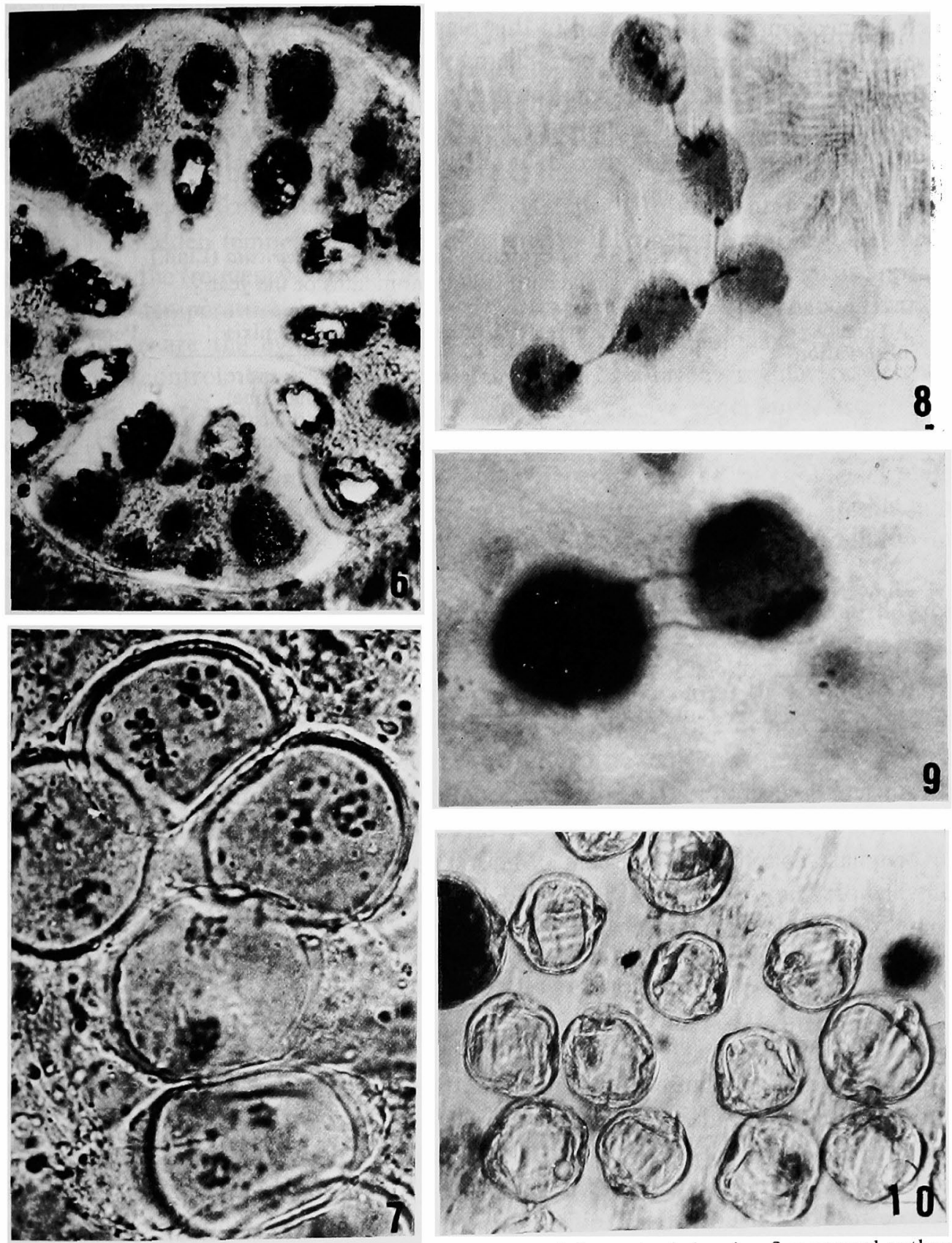

Figs. 6-10. 6, T.S. through the corolla tube of a matured flower bud showing five normal anthers each with four lobes. 7, PMC's showing abnormal chromosome number in each pole at anaphase I. $\times 2620$ (approx.) 8 , cytoplasmic connection and stretched nuclear material in a series of PMC's. $\times 1260$ (approx.) 9, PMC's showing two cytoplasmic connections during cytomixis. $\times 1990$ (approx.) 10, pollen grains showing a high percentage of smaller empty pollen. 
tightly packed within the basal region of a narrow corolla tube. Morphological and histological studies showed that all anthers developed equally without any deformation in shape (Fig. 6). No variation was observed among different regions of an anther in the intensity of cytomixis. Pollen mother cells with cytomictic connections were well spread and spontaneous transfer of chromatin material through such connections was rarely seen in this plant. Pollen mother cells with abnormal chromosome number in each pole at anaphase were observed (Fig. 7). In some case, a series of PMCs were connected and nuclear material was found to stretch across and invade the cytoplams of neighbouring cells (Fig. 8). Sometimes adjacent PMCs were linked by two or more cytoplasmic channels of varying breadth (Fig. 9).

Table 1. Percentage of cytomixis in Ervatamia divaricata (Linn.)

Alston var. single during different months of the year

\begin{tabular}{|c|c|c|c|c|}
\hline \multirow{2}{*}{$\begin{array}{l}\text { Time of } \\
\text { observation }\end{array}$} & \multirow{2}{*}{$\begin{array}{l}\text { Total no. } \\
\text { of cells } \\
\text { observed }\end{array}$} & \multicolumn{2}{|c|}{ No. of cells showing cytomixis } & \multirow{2}{*}{$\begin{array}{l}\text { Percentage } \\
\text { of cytomixis }\end{array}$} \\
\hline & & $\begin{array}{l}\text { with one } \\
\text { cytoplasmic } \\
\text { connection }\end{array}$ & $\begin{array}{l}\text { with more } \\
\text { than one } \\
\text { cytoplasmic } \\
\text { connection }\end{array}$ & \\
\hline February & 128 & 5 & 1 & 4.69 \\
\hline March & 85 & 11 & - & 12.94 \\
\hline April & 99 & 8 & 3 & 11.11 \\
\hline May & 127 & 10 & 1 & 8.66 \\
\hline June & 86 & 11 & 1 & 13.95 \\
\hline
\end{tabular}

In the present study, cytomixis was observed in almost every stage, starting from prophase to tetrad condition of pollen mother cells. It was more frequent in prophase and in early telophase of first meiotic division than in other stages of meiosis. Again, in prophase, cytomixis was more common in early stages when the nucleolus was found to be present along with chromatin lumps. No cytoplasmic connection between PMCs at different phase of meiosis viz. prophase-telophase I, or prophase-anaphase I was seen. Meiotic abnormalities include lagging (4.12)\%, univalent formation $(6.24 /$ cell), early $(6.37 \%)$ and late separation $(1.12 \%)$ of chromosomes. Two types of pollen were seen-larger filled grains and smaller aborted empty grains (Fig. 10). Pollen sterility was found to be $97 \%$ (approx.)

\section{Discussion}

The underlying cause of cytomixis has been interpreted variously by different authors, including abnormal pathological condition (Bobak and Herich 1978, Morisset 1978), effect of fixation (Linnert 1955, Takats 1959, Woodworth 1931) as well as a genetically controlled behaviour (Brown and Bertke 1974). Its significance too has been assessed differently including the possibility of occurrence of aneuploidy (Bell 1964, Cheng et al. 1975, Kamra 1960, Omara 1976, Salesses 1970, Sarvella 1958, Srivastav and Raina 1980). Extrusion of chromatin and cytomixis in pollen mother cells may have serious repercussions on the viability of the gametes as well. 
In the present investigation extensive occurrence of cytomixis has been recorded in pollen mother cells of Ervatamia divaricata var. single. Connections between the pollen mother cells were found to be Feulgen-positive suggesting transfer of chromatin material from one to the other. In some cases, even direct fusion was observed. Occasionally cytomixis has involved even five pollen mother cells in a row. This behaviour has been noted in most of the anthers from different plants so far studied. Cells at early prophase I and telophase I showed a greater frequency of cytomixis as compared to metaphase. Surface adhesion undoubtedly plays an important role in the formation of such connections. Cytomictic pollen mother cells have, however, been observed throughout the year. The maximum frequency has been observed from March to June, that is, prior to the onset of monsoon (Table 1). Sudden temperature fluctuation due to intermediate showers, has been seen to affect the frequency. It is reported that in Hemerocallis sp. cytomixis appears to be due to temperature fluctuations leading to physiological disturbance (Narain 1970). These are the evidences which show that the physiological factors to a great extent control the manifestation of cytomixis. But the regular occurrence of this behaviour in all the individuals and in successive years suggests genetics control. Possibly this species is genetically endowed with the property of undergoing cytomixis, the manifestation of which depends on the physiological state of the tissue. It is, however, to be noted that abnormality in anther production is not the cause of cytomixis as clearly indicated by regular anther formation in diploid plants.

The occurrence of such a cytomictic condition in this species is important in that, it is associated with high pollen sterility and no seed formation. However, mere cytomixis, which occurs at a maximum frequency of $13.9 \%$, cannot account entirely for the very high percentage ( $97 \%$ approx.) of pollen sterility recorded here. Obviously, other genetic factors are also involved. In this connection it may be recorded that cells have been observed with irregular chromosome numbers in two different nuclei, possibly arising out of non-disjunction. Such nuclei may also lead to formation of non-viable pollen. However, cytomixis, coupled with irregular number and other genetic factors may contribute to the failure of sexual reproduction and consequently to apomictic reproduction. In spite of the possibility of production of aneuploids by cytomixis, the absence of seed setting in this species does not indicate any significant role of cytomixis in generating variability in $E$. divaricata.

\section{Summary}

Cytomixis has been observed throughout the year in the pollen mother cells of an apomictic ornamental Ervatamia divaricata (Linn.) Alston (var. single). The frequency of cytomixis was found to be more $(8.66-13.95 \%)$ during the months of March to June in all the plants. Direct fusion of two pollen mother cells and involvement of a series of PMC's by one or more cytoplasmic connections were also noted.

The regular occurrence of this behaviour in all the individuals and in successive 
years suggests the possibility of genetic control of the process, manifestation being dependent on physiological state of the tissue. Cytomixis, coupled with irregular number and other genetic factors, might have contributed to the failure of sexual reproduction. The absence of seed setting does not indicate any significant role of cytomixis in generating variability in this species.

\section{Acknowledgement}

The financial help received from the Department of Science and Technology, New Delhi, in the form of a Research Project is gratefully acknowledged. Sincere thanks are also due to Professor (Mrs.) Archana Sharma, Head of the Department of Botany, University of Calcutta, for providing facilities.

\section{References}

Bell, C. R. 1964. Cytomixis in Tauschia nudicaulis Schlecht (Apiaceae). Cytologia 29: 396-398. Bobak, M. and Herich, R. 1978. Cytomixis as a manifestation of pathological changes after the application of trifluraline. The Nucleus $21: 22-26$.

Brown, W. V. and Bertke, E. M. 1974. Textbook of cytology, 2nd Ed. The C. V. Mosby Co., Saint Louis.

Cheng, K.-C. 1974. Cytomixis. Acta Genet. Sin. 1: 117-124. In Chinese. Quoted from Biol. Abstr. 62: 35994, 1976.

-, Nieh, H.-W., Yang, C.-L. Wang, I.-M., Chou, I.-S. and Chen, J.-S. 1975. Light and electron microscopical observations on cytomixis and the study of its relation to variation and evolution. Acta Bot. Sin. 17: 60-69. In Chinese. Quoted from Biol. Abstr. 62: 1090, 1976.

Cooper, D. D. 1952. The transfer of deoxyribose nucleic acid from the tapetum to the microsporocytes at the onset of meiosis. Am. Nat. 86: 219-229.

Gottschalk, W. 1970. Chromosome and nucleus migration during microsporogenesis of Pisum sativum. The Nucleus 13:1-9.

Jacob, K. T. 1941. Certain abnormalities in the root tips of cotton. Curr. Sci. 10: 174-175.

Kamra, O. P. 1960. Chromatin extrusion and cytomixis in pollen mother cells of Hordeum. Hereditas 46: 592-600.

Linnert, G. 1955. Cytologische Grundlagen für Sterilitätserscheinungen in der Gattung Salvia. Der Züchter 25: 237-241.

Morisset, P. 1978. Cytomixis in pollen mother cells of Ononis (Leguminosae). Can. J. Genet. Cytol. 20 : 383-388.

Narain, P. 1979. Cytomixis in the pollen mother cells of Hemerocallis Linn. Curr. Sci. 48: 996998.

Omara, M. K. 1976. Cytomixis in Lolium perenne. Chromosoma 55: 267-271.

Salesses, G. 1970. Sur le phénomene de cytomixie chez des hybrides triploides de prunier. Conséquences génétiques possibles. Ann. Amelior, Plant. 20: 383-388.

Sarvella, P. 1958. Cytomixis and the loss of chromosomes in meiotic and somatic cells of Gossypium. Cytologia 23: 14-24.

Semyarkhina, S. Ya. and Kuptsou, M. S. 1974. Cytomixis in various forms of sugarbeet. Vests I AN BSSR. Ser. biyal. 4: 43-47.

Sharma, A. K. and Sharma, A. 1980. Chromosome Techniques-theory and Practice. 3rd Ed. Butterworths \& Co. Pub. Ltd., London.

Srivastav, P. K. and Raina, S. N. 1980. Cytomixis in Clitoria ternatea L. var, pleniflora Fantz. F. pleniflora. Curr. Sci. 49: 824-835. 
Takats, S. T. 1959. Chromatin extrusion and DNA transfer during microsporogenesis. Chromosoma 10: 430-453.

Tarkowska, J. 1960. Cytomixis in epidermis of scales and leaves and in meristems of the root apex of Allium cepa L. Acta Soc. Bot. Polon. 29: 149.

- 1965. Experimental analysis of the mechanism of cytomixis I. Cytomixis in vegetative tissues. Acta Soc. Bot. Polon. 34: 27-44.

Woodworth, R. H. 1931. Cytomixis. J. Arnold Arbor., Harvard Univ. 12: 23-25. 